\title{
Współmyślenie poza Północą i Południem: Przedmowa do tłumaczenia
}

Publikacją tekstu „W poszukiwaniu Globalnego Wschodu: Myślenie między Północą a Południem” autorstwa Martina Müllera, szwajcarskiego geografa i badacza miejskiego, pragniemy zainaugurować dyskusję dotyczącą geopolitycznych uwarunkowań perspektyw epistemologicznych wywodzących się z regionu, który doświadczył realnego socjalizmu. Nie obawiając się konsekwencji strategicznego esencjalizowania, któremu być może nieco bezkrytycznie poddaje się Müller, wychodzimy z przekonania, że po latach dyskusji przesiąkniętych postmodernistyczną różnicą obecną w perspektywach postkolonialnych, stanowisko zaproponowane w publikowanym przez nas artykule jest powiewem świeżego powietrza.

Choć niewidzialny, celowo zapomniany, Drugi Świat z jego doświadczeniami socjalistycznych projektów państwowych, jak również oddolnej, robotniczej walki o ich postępującą komunizację, staje się współcześnie coraz częstszym punktem odniesienia w refleksji teoretycznej. Mimo to takie praktyki wciąż lokują się na marginesie. Wyparcie historycznego doświadczenia Wschodnich projektów socjalistycznej modernizacji i ich komunistycznych korekt postrzegamy jako część szerszego wysiłku na rzecz wzmacniania antykomunistycznej hegemonii w sferze społecznej wyobraźni. Pierwszym krokiem, który w walce o odzyskanie społecznej wyobraźni antykapitalistycznej w Polsce czy innych krajach regionu należy uczynić, jest w naszej opinii zmierzenie się z lekcją, której udziela nam myślenie poza opozycją Północy i Południa. W innym 
wypadku, „w Polsce” zawsze będzie oznaczać, jak w Ubu królu Jarry’ego, nigdzie.

Chcąc potraktować poważnie, zaproszenie sformułowane przez Müllera w konkluzji jego artykułu - by wspólnie myśleć o Wschodzie i sposobach, na jakie jego materialne uwarunkowania wpływają na kształt i kierunki refleksji praktyczno-teoretycznej - w kolejnym numerze opublikujemy głosy w dyskusji przygotowane przez polskich badaczy i badaczki, którym nieobce są problemy kondycji peryferyjnej. Magda Szcześniak, Jan Sowa, Tomasz Zarycki czy Adam Leszczyński, udzielili nam rozbudowanych i krytycznych komentarzy, odsłaniających przede wszystkim polityczne i ekonomiczne wątki, które perspektywa strategicznego esencjalizowania powinna w najbliższym czasie podjąć, jeśli w ogóle można je na jej gruncie rozwijać. Poprosiliśmy autora prezentowanego tekstu o ustosunkowanie się do tych komentarzy i jego odpowiedź opublikujemy obok tych głosów w kolejnym numerze. Nie chcielibyśmy jednak kończyć naszej dyskusji w ten sposób. Łamy Praktyki Teoretycznej pozostają otwarte na głosy dążące do dalszej eksploracji projektu regionalnego „uwspólniania”.

Cytowanie: Praktyka Teoretyczna. 2020. „Współmyślenie poza Północą i Południem: Przedmowa do tłumaczenia." Praktyka Teoretyczna 3(37): 155-156.

DOI: $10.14746 /$ prt2020.3.7 